\title{
A Day in the Life of a Range Conservationist, or Rolled Milo
}

\section{A former range conservationist recalls working with one of his favorite ranchers.}

\author{
By Randy Donges
}

"I think I have just enough time to get to the elevator before it closes and pick me up a load of rolled milo." I guess I'll never forget those words.

Myron was a crusty old character. He'd been running cattle longer than I'd been breathing. He was thin and bow-legged and had that sort of permanent grin that comes from nearly 70 years of squinting at the sun. You could never tell whether he was about to make a wisecrack or if the sun was just in his eyes. It was about a fifty-fifty chance.

His beat-up silverbelly hat looked as old as he was, and I rarely saw it off his head. I guess he knew everybody in the county. I'm pretty sure everybody in the county knew him. I met him in ' 97 when I was a range conservationist in Oklahoma. He came into the office one afternoon looking for information on grazing Old World bluestem. I welcomed his visit because it broke up my routine of government paperwork and let me actually talk grazing with someone.

We hadn't talked more than five minutes when he suggested going to the coffee shop. I later learned that the coffee shop was his proxy office,

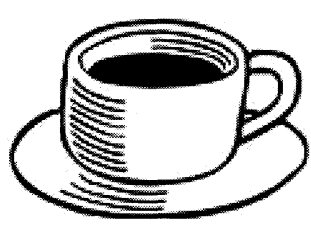
and he faithfully checked in to the office several times a day. We sat there drinking coffee and talking for the better part of three hours that day. We talked about everything from raising cattle to raising kids to raising Cain. As it turned out, we had been born in the same county in north Texas, nearly 30 years apart.

I managed to squeeze out of him that he had a college degree in agriculture. You'd never know it to look at him or listen to him. He had that attitude typical of men like him, that talking about what you know is equivalent to "putting on airs." He had a real interest in cattle nutrition, and that became a favorite topic of conversation for us over the next couple of years.
Not long after that first meeting I was sitting at home one Saturday morning when the phone rang. It was Myron. He was short-handed and wondered if I could help work cattle that day. I hadn't cowboyed full time in over ten years, so the only chance I got to blow the dust off my saddle was when somebody needed help like this. I considered it recreation and a nice break from the government desk job that had turned me into a soft blob. I met him at his horse trap on the edge of town and we spent the day gathering cattle and sorting cattle and hauling cattle all over the county.

Myron had quite an operation. He owned or leased parcels of land in every corner of the county, and I guess he had bovines on every parcel. Some of the pastures didn't have water and had to have it hauled to them. Some were used for cows, some were used for stockers, and some were used for anything that happened to need grass at the time. Most of his pastures were native range, and of those, most were short grass prairie. He was a good grazier, and overall his land was in good condition.

I continued to help with those occasional cow-shufflings, and we always had some interesting conversations while riding through a pasture or driving down the road. We worked well together. Myron had an easy, patient way with cattle. We seemed to know what the other was about to do, so we didn't get in each other's way or chouse the cattle. We got our work done with minimal stress to ourselves and to the critters.

The subject of feeding grain to grazing cattle came up early. We were going to check some yearlings on wheat pasture one morning and he had to stop at the local grain elevator to pick up a load of rolled milo for the yearlings. "Why?" I asked. I'd

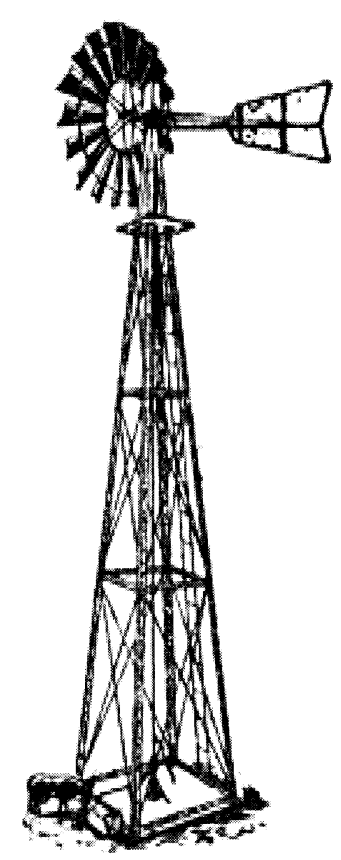


never heard of feeding grain to cattle on wheat. I know people feed it on range, and most of the time shouldn't be. But wheat pasture? That had me scratching my head.

In his slow drawl, Myron said "Aw, I just like to give "em a little boost."

"A boost of what?" I thought. Diet quality certainly isn't a problem on wheat pasture, and with the good moisture we'd had that winter, his pastures weren't limiting in quantity. But I let it go, and we dumped a lot of dollars in the troughs he had scattered around the pastures that day.

As I got to know Myron better and got more comfortable questioning him, we got into more lengthy discussions on nutrition in general, and feeding grain in particular. He even got to the point where he'd ask me what I thought about one thing or another, and if the subject was cattle diet supplementation, I always gave the same song and dance.

"You know Myron, I'm not a nutritionist, but from everything I was told in school and everything I've read by nutritionists, feeding grain to cattle on a forage diet is counterproductive. If forage quantity is the problem, then feeding hay is more economical for filling the cattle. And if forage quality is the problem, then feeding a higher protein feedstuff like cottonseed meal or soybean meal or one

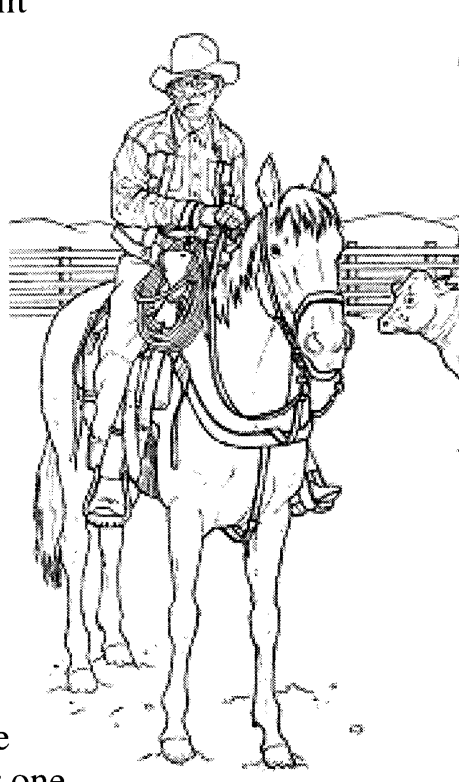
of the commercial protein supplements better enables the rumen to digest the low quality forage. Grain doesn't do that as effectively. And they also say that grain consumption by grazing cattle actually decreases forage intake. So the cattle don't even make the best use of the forage that's available."

I must have gone through that speech a dozen times with him. I always tried to be careful in the way I said it, and put it in a way that it wasn't I, but the experts who say this stuff. He'd always nod, and sometimes we'd discuss it some more, and sometimes the subject would just change. And he just kept on buying and feeding rolled milo. We did that right up until the last time I worked with him.

It was one of those cold, still mornings in mid-March. Everything was covered with frost and the eastern sky was just beginning to glow as we saddled our horses. I had taken off work to help Myron ship all his wheat pasture cattle to the sale barn. It was going to be a long day of gathering cattle, loading them on trucks, loading our horses on a trailer, moving to another pasture, and starting over again.

Myron had me mounted on a young blue roan gelding he had just got in one of his famous trades. He kept good saddle horses and you could usually count on being well mounted when you rode for him. This was a good looking horse with nice conformation and a big, soft eye. He seemed to have a calm disposition, but he acted like he might be feeling a little froggy on that cold morning. I climbed aboard and turned him a few times and was glad to see that he didn't have immediate plans to shortcircuit and unload my desk-chair shaped posterior onto that cold, hard ground.

We had a high school kid riding with us that morning. I didn't ask him what he was doing out of school. He was a fair hand a-horseback and had the same easy way with cattle as Myron. I guess he had been around Myron enough to soak up some of his cow knowledge. Maybe that's what he was doing out of school. It was the same thing I was doing off work.

Myron used the livestock auction in the next county because he thought he got better prices there. I kinda suspected he liked the coffee better. But in either case, it took the trucks a while to get unloaded and get back to us in the next pasture, so we usually had cattle waiting by the time they got back. We gathered pastures and loaded trucks non-stop and finished up by about four that afternoon. The work had been real smooth, without any "happenings" as Myron called breakaway cattle or busted gates or flat tires.

We hadn't stopped for lunch or even for coffee breaks, and we were tired. We unsaddled our horses and loaded them in the trailer and started the long drive back to the horse trap. It was a quiet drive when out of the blue Myron said "I think I'm gonna try feeding some of that cottonseed meal one of these days. What do you think about that?"

After I gathered my chin up off my chest I said "I think that'd be great. You know Myron, I'm not a nutritionist, but from everything I was told in school and everything I've read by nutritionists, feeding grain to cattle on a forage diet is ..."

I finished my standard sermon and he nodded and we resumed our tired silence. I sat there thinking "Now this 
is what being a range con is all about. It's taken me two years, but I've had an effect on how this man is going to do business. We're going to get him off that derned rolled milo and his cattle are going to benefit and his bank account is going to benefit. It was worth the time and effort. And now that he's going to be using the right kind of supplement, I can start working on him to use it at the right time. There's no rhyme or reason to when he supplements his cattle. But this is a good start. Maybe I'll hit him up about using the forage quality testing program I've been using with a couple of other ranchers. We're going to make some real progress now!"

He pulled into his horse trap and stopped beside my pickup at the corral and opened his checkbook. I always felt guilty about getting paid for riding with him all day and getting some exercise and picking his brain. And I always argued with him. And he always insisted on paying me. So we went through our little routine and he handed me a check and said "Randy, I'm much obliged for your help. I think I have just enough time to get to the elevator before it closes and pick me up a load of rolled milo."

What could I say? "I enjoyed it, Myron. Holler if you need anything." I dragged my saddle out of the back of his pickup and watched him drive away.

Author is a former federal Rangeland Management Specialist. He currently works as a computer systems analyst to keep creditors at bay, and as a private grazing consultant to keep his hand in range. It is unknown at this point whether or not Myron is still feeding rolled milo.

\title{
UNIVERSITY OF CALIFORNIA \\ COOPERATIVE EXTENSION
}

\section{Resource Management and Water Quality Advisor}

\author{
San Joaquin and Stanislaus Counties
}

\#ACV 02-05

The UNIVERSITY OF CALIFORNIA, DIVISION OF AGRICULTURE AND NATURAL RESOURCES, COOPERATIVE EXTENSION is seeking career-track academic candidate to develop and implement Cooperative Extension education and applied research programs in ecosystem management \& restoration, agriculture and wildland interactions, and watershed management and water quality.

Academic appointees in UC Cooperative Extension are responsible for conducting a balanced program comprised of extending knowledge and information, applied research, maintaining professional competence, in addition to University and public service.

A Master's degree in conservation biology, restoration ecology, biology, resource management, environmental education, or a closely related field is required. Specialty and/or professional experience must provide a significant understanding of $\mathrm{ag} / \mathrm{urban} /$ resource management interface policy resolution and compliance with related environmental laws and regulations. Undergraduate degree in agronomy, plant/animal sciences, or range management is desirable.

Beginning salary will be in the UC Cooperative Extension Assistant Advisor rank, DOQ. See CE Advisors salary scale at http://www.ucop.edu/acadadv/acadpers/tab0102/table33.pdf. The full position vacancy announcement and required application are available at http://cvr.ucdavis.edu or contact Cindy Inouye, UC Cooperative Extension Central Valley Region, 9240 Riverbend Ave., Parlier, CA 93648; email cinouye@ uckac.edu, phone (559) 646-6535. Complete packets must be received by August 21, 2002. Refer to position \#ACV 02-05. AA/EOE 